\title{
An Immunohistochemical Demonstration of Neuron-Specific Enolase in the Merkel Cells of the Frog Taste Organ
}

\author{
Kuniaki Toyoshima and Akitatsu ShImamura \\ Department of Oral Anatomy, Kyushu Dental College, Kitakyushu, Japan
}

Received April 18, 1988

Summary. The Merkel cells in the taste organ of the frog were investigated by immunohistochemistry using neuron-specific enolase (NSE) antiserum. NSE-immunoreactivity was found exclusively in the Merkel cells lying at the base of the taste organ. The distribution and the profiles of the NSE-immunoreactive Merkel cells coincided with serotonin-containing cells previously reported at the same place.

It has been reported that a distinct type of cell showing a serotonin-like monoamine fluorescence exists in the basal portion of the frog taste organ (HIRATA and NADA, 1975, 1977; EsAKOV et al., 1984). Electron microscope studies have demonstrated that these cells conform in most aspects to Merkel cells (DÜRING and ANDRES, 1976; TOYOSHIMA and SHIMAMURA, 1982; Toyoshima et al., 1984). Recent immunohistochemistry has provided evidence that the Merkel cells in the mammalian (Gu et al., 1981) as well as teleostean skin (ZACCONE, 1984, 1986) are immunoreactive for neuron-specific enolase (NSE), which is an isozyme of the glycolytic enzyme enolase originated in neurons. Thus, it has been suggested that NSE may be one of the marker substances for Merkel cells as well as for other paraneurons. The present study investigates whether NSE immunoreactivity might be detected in particular Merkel cells at the base of the frog taste organ.

\section{MATERIALS AND METHODS}

The tongues from six adult frogs (Rana $n$. nigromaculata), anesthetized with ether, were removed, cut into small blocks and fixed for $3 \mathrm{~h}$ in Bouin's fixative containing no acetic acid. The tissue specimens were then rinsed overnight at $4^{\circ} \mathrm{C}$ with phosphate buffer $(\mathrm{pH} 7.3)$ containing $7 \%$ sucrose and embedded in paraffin. Dewaxed $5 \mu \mathrm{m}$ thick sections were incubated in the rabbit polyclonal antiserum against cow NSE (Dako Co.) (1:300) overnight at $4^{\circ} \mathrm{C}$ and submitted to the peroxidase-antiperoxidase (PAP) method. Control sections were treated with non-immunized rabbit serum prior to incubation with the first antiserum.

\section{RESULTS AND DISCUSSION}

The taste organ is composed of at least three kinds of cell types: taste, supporting, and Merkel cells. The taste and supporting cells extend throughout the entire thickness of the taste organ, while the Merkel cell is located only in its basal portion.

The Merkel cells in the taste organ were found to exhibit immunoreactivity with NSE antiserum (Figs. $1 \mathrm{a}, \mathrm{b})$. The number of the immunoreactive Merkel cells varied from 12 to 18 in a taste organ. The strongest immunoreactivity was found in the perinuclear cytoplasm located at the periphery of the base of the taste organ.

When sectioned horizontally just above the basal lamina, the entire profiles of the cells were demonstrated (Figs. 1c, d). The cytoplasmic process of the Merkel cell tapered along the basal lamina toward the center of the taste organ. The inner end was relatively wide and irregular in shape.

In control sections preincubated with nonimmunized rabbit serum, positive staining was completely absent from the taste organ.

The results of the present study have revealed that 

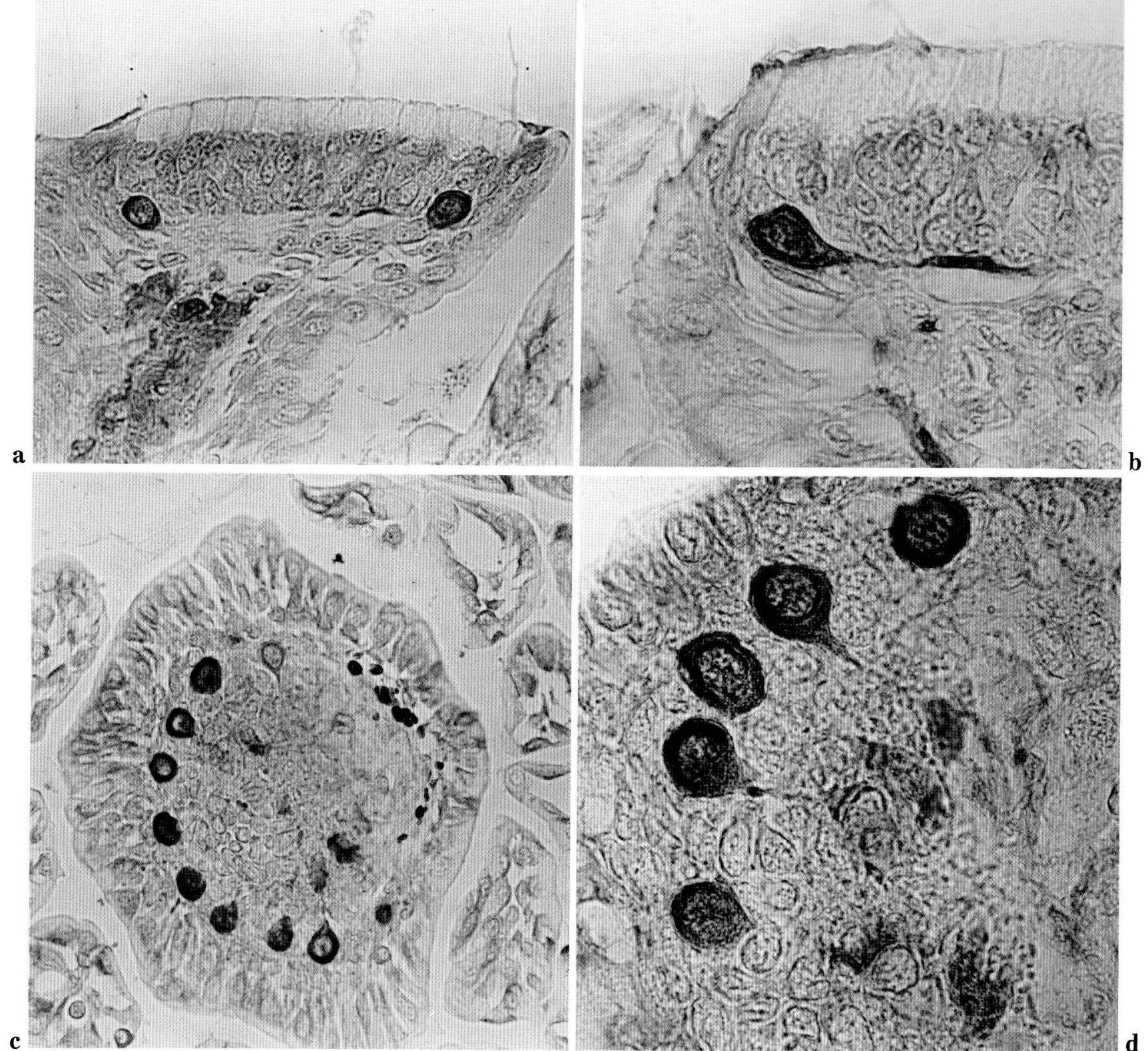

Fig. 1. Light micrographs of frog fungiform papillae immunostained with antiserum to NSE. NSEimmunoreactive Merkel cells are found in transverse $(\mathbf{a}, \mathbf{b})$ as well as oblique $(\mathbf{c}, \mathbf{d})$ sections through taste organs. $\mathrm{a}: \times 540, \mathrm{~b}: \times 1,100, \mathrm{c}: \times 500, \mathrm{~d}: \times 1,300$

the Merkel cells in the frog taste organ are immunoreactive for NSE antiserum. The distribution and the profiles of the Merkel cells coincided completely with those of serotonin-like monoamine-containing cells reported by HiRATA and NADA $(1975,1977)$. Thus, it is probable that the Merkel cells in the frog taste organ contain both NSE and serotonin-like monoamine.
This is in accord with observations by ZACCONE (1986), in which the Merkel cells in the skin of the conger eel are immunoreactive for both NSE and serotonin antisera. Ultrastructurally, the Merkel cells in the frog taste organ contain numerous dense-core granules, a characteristic of this cell type (DÜRING and ANDRES, 1976; TOYOSHIMA and SHIMAMURA, 1982; 
Toyoshima et al., 1984). It is likely that the dense-core granules are storage sites for monoamine (NADA and HiRATA, 1975; HiRATA and NADA, 1977; TOYOSHIMA et al., 1984). On the other hand, it has been reported that NSE is stored in the non-granular, cytosolic portion of the cytoplasm (VINORES et al., 1984). Recent immunohistochemistry also has provided evidence that the Merkel cells of mammalian skin are immunoreactive for met-enkephalin (HARTSCHUH et al., 1979) and vasoactive intestinal polypeptide (VIP) (HART. SCHUH et al., 1984). The physiological significance of these bioactive substances in the Merkel cells is not yet fully understood.

It has been reported that the Merkel cells in the frog taste organ maintain their characteristics ultrastructures after a long period of denervation (ToYOSHIMA et al., 1984). It would be of interest to know whether denervated Merkel cells are also immunoreactive for NSE antiserum. These answers await future investigations.

Addendum. After submission of this manuscript, this jounrnal published an excellent paper by H. KURA . мото: An immunohistochemical study of cellular and nervous elements in the taste organ of the frog, Rana catesbeiana (Arch. Histol. Cytol. 51: 205-221, 1988). He observed NSE-immunoreactivity in the gustatory cell and serotonin-immunoreactivity in the basal cell, a type of Merkel cell.

Acknowledgements. We thank Mrs. Kyoko OKADA for expert technical assistance.

\section{REFERENCES}

Düring, M. v. and K. H. ANDRes: The ultrastructure of taste and touch receptors of the frog's taste organ. Cell Tiss. Res. 165: 185-198 (1976).

Esakov, A. I., N. A. Solovieva and E. M. Krokhina: Effects of tryptophan and 5-hydroxytryptophan on the number of monoamine-containing cells in the frog taste buds. Chem. Senses 9: 303-309 (1984).

Gu, J., J. M. Polak, F. J. Tapia, P. J. Marangos and A. G. E. Pearse: Neuron-specific enolase in the Merkel cells of mammalian skin. The use of specific antibody as a simple and reliable histologic marker. Amer. J. Pathol. 104: 63-68 (1981).
Hartschuh, W., E. Weine, M. Buchler, V. Helmsstaedter, G. E. Feurle and W. G. ForssmanN : Met-enkephalinlike immunoreactivity in Merkel cells. Cell Tiss. Res. 201: 343-348 (1979).

Hartschuh, W., M. Reinecke, E. Weihe and N. YanaIHARA: VIP-immunoreactivity in the skin of various mam-

mals: immunohistochemical, radioimmunohistochemical and experimental evidence for a dual localization in cutaneous nerves and Merkel cells. Peptides 5: 239-245 (1984).

HiRATA, K. and O. NADA: A monoamine in the gustatory cells of the frog's taste organ. A fluorescence histochemical and electron microscopic study. Cell Tiss. Res. 159: 101-108 (1975).

- Cytoarchitecture of monoaminecontaining cells in the frog's gustatory epithelium. Experientia 33: 1223-1224 (1977).

Nada, 0. and K. Hirata: Specific effect of 5, 6-dihydroxytryptamine on the monoamine fluorophore of the frog's gustatory cells. Histochemistry 45: 121-127 (1975).

Toyoshima, K. and A. Shimamura: Comparative study of the ultrastructures of the lateral-line organs and the palatal taste organs in the African clawed toad, Xenopus laevis. Anat. Rec. 204: 371-381 (1982).

Toyoshima, K., E. Honda, S. Nakahara and A. ShimaMURA: Ultrastructural and histochemical changes in the frog taste organ following denervation. Arch. Histol. Jap. 47: 31-42 (1984).

Vinores, H., M. M. Herman, L. J. Rubinstein and P. J. MARANGOS: Electron microscopic localization of neuronspecific enolase in rat and mouse brain. J. Histochem. Cytochem. 32: 1295-1302 (1984).

ZACCONE, G.: Immunohistochemical demonstration of neuron-specific enolase in the nerve endings and skin receptors of marine eels. Histochem. J. 16: 1231-1236 (1984).

- Neuron-specific enolase and serotonin in the Merkel cells of conger-eel (Conger conger) epidermis. An immunohistochemical study. Histochemistry 85: 2934 (1986).

\author{
Dr. Kuniaki Toyoshima \\ Department of Oral Anatomy \\ Kyushu Dental College \\ Kokurakita-ku, Kitakyushu \\ 803 Japan \\ 豊島邦昭 \\ 803 北九州市小倉北区真鶴 2-6-1 \\ 九州歯科大学 \\ 第二口腔解剖学教室
}

